\begin{tabular}{|l|l|l|}
\hline \multicolumn{2}{|c|}{ PublisherInfo } \\
\hline \hline PublisherName & $:$ & BioMed Central \\
\hline \hline PublisherLocation & $:$ & London \\
\hline \hline PublisherImprintName & $:$ & BioMed Central \\
\hline \hline
\end{tabular}

\title{
Cell biology in orbit
}

\begin{tabular}{|l|l|l||}
\hline \multicolumn{2}{|c|}{ ArticleInfo } \\
\hline \hline ArticleID & $:$ & 3896 \\
\hline \hline ArticleDOI & $:$ & $10.1186 /$ gb-2001-2-11-reports0043 \\
\hline \hline ArticleCitationID & $:$ & reports0043 \\
\hline \hline ArticleSequenceNumber & $:$ & 21 \\
\hline \hline ArticleCategory & $:$ & Paper report \\
\hline \hline ArticleFirstPage & $:$ & 1 \\
\hline \hline ArticleLastPage & $:$ & 5 \\
\hline \hline & & RegistrationDate : 2001-8-20 \\
\hline ArticleHistory & $:$ & Received \\
\hline ArticleCopyright & $:$ & BioMed Central Ltd2001-8-20 \\
\hline \hline ArticleGrants & $:$ & \\
\hline \hline ArticleContext & $:$ & 13059221111 \\
\hline \hline
\end{tabular}




\section{Abstract}

The effects of launch vibrations and microgravity on the cytoskeletal organization of a Jurkat leukemic cell line flown in space have been identified using a microarray approach.

\section{Significance and context}

A number of cell types (muscle, kidney, immune cells and osteoblasts) and a variety of effects of microgravity on cellular functions have been studied during flights of the Space Shuttle. Two observations have been made consistently: growth arrest of the cells and poor response to mitogens. With hundreds of genes involved in such responses, it was previously impossible to pick out those responsible for the observed anomalies. A logical next step was, therefore, to apply a more global analytical approach. Lewis et al. have now performed a first microarray analysis of immune cells flown in space. Figure 1 shows a diagram of the in-flight cell-culture unit used. Having identified around 400 genes that were differentially expressed in space-flown samples, they focused on the changes in expression of genes for cytoskeletal components, as these can significantly affect cellular functions. The expression of these genes was validated through reverse-transcriptase-coupled (RT) PCR and immunofluorescence. 
Figure 1 A fully automated cell-culture unit used

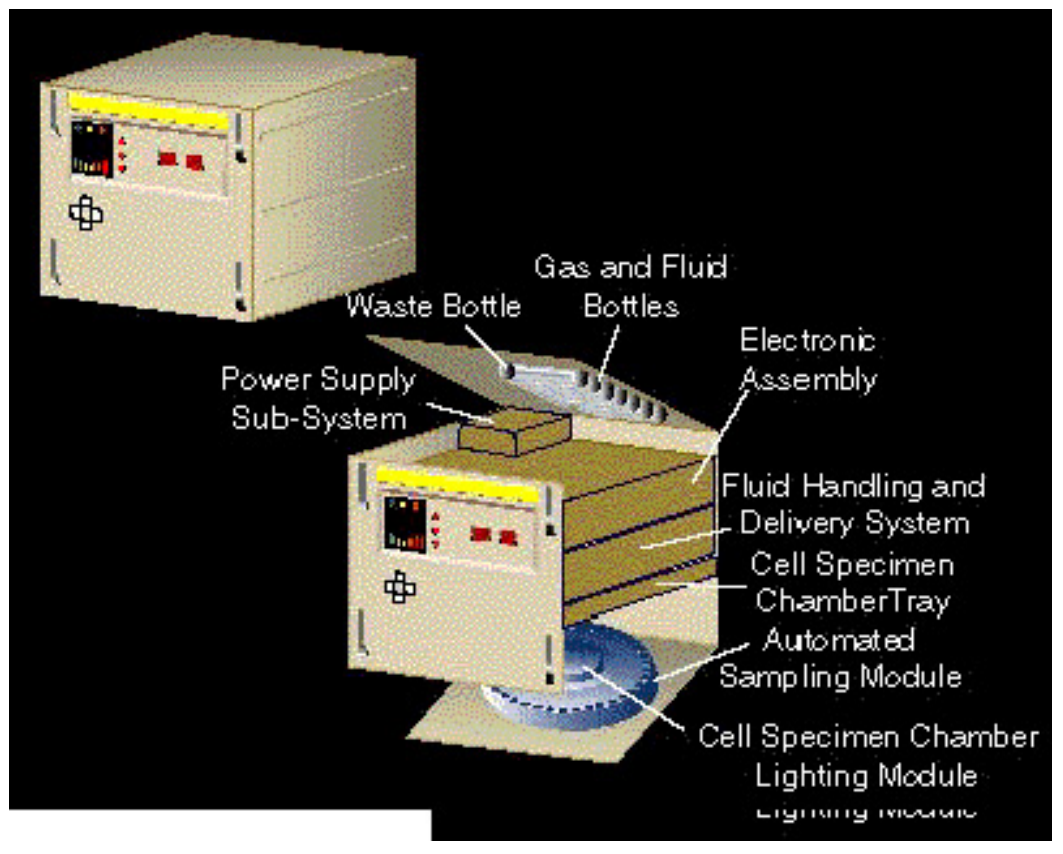

\section{Key results}

The authors used nylon-based microarrays to screen samples from space-flown, launch and ground controls of anchorage-independent T-leukemia cells of the Jurkat cell line. Only around 2\% of genes (approximately 400) were differentially expressed, with only a few of the genes downregulated in space. Changes were observed in genes encoding proteins regulating metabolism, in apoptosis genes, and in genes for cytoskeletal components, growth and cell-cycle regulators, cell adhesion molecules, transcription factors, tumor suppressors and signal transduction proteins. Among these genes, ten encode cytoskeletal proteins (plectin, ankyrin, C-NAP1, actin-like protein, calponin, tropomodulin, myosin, dynactin, keratin and myosin light chain) that were upregulated after 48 hours of space flight and only one, encoding a gelsolin precursor, was downregulated.

Most importantly, the effects of the launch vibrations were investigated separately from those of flight, allowing genes that were differentially expressed as a result of microgravity in orbit to be identified. Launch of the Shuttle itself caused a dramatic disorganization of the microtubules, which was repaired 24 hours after simulated launch. There were, however, indications that despite the normalization of the cytoskeleton the cells did not grow. 


\title{
Links
}

A listing of all the genes differentially regulated during space flight and simulated launch can be found on the Space flight data site maintained by Marian Lewis.

\section{Conclusions}

Lewis et al. identified genes encoding cytoskeletal proteins that are differentially expressed in spaceflown $T$ cells. They suggested that the observed differences can lead to abnormal reassembly of the cytoskeleton in microgravity.

\section{Reporter's comments}

Whole-genome analysis is shown to be a powerful technique for looking at changes induced in cells in space. As the results are analyzed, future experiments can be planned to make the most efficient use of astronauts' time and available space. Although an important paper because it is the first global analysis of immune cells flown in space, it does have some problems. A key one is that the Shuttle launch was simulated on the ground by vibrating the samples. It will be important to compare the profiles of cells vibrated on ground with those from a real in-flight launch.

Future work should include analysis of all samples on large arrays (20,000 genes) and an assessment of protein synthesis and modification, which would give a better indication of cellular function. A proteomic approach would also allow to analyze the heavily post-translationally regulated cytoskeletal proteins, an aspect that cannot be addressed by microarray analysis. Also, an analysis of more time points would be useful to assess whether the cells begin to grow after 48 hours. Finally, the most important issue to be addressed is the ability of immune cells to respond to an antigenic challenge under microgravity.

\section{Table of links}

\author{
FASEB Journal
}

Space flight data 


\section{References}

1. Lewis ML, Cubano LA, Zhao B, Dinh HK, Pabalan JG, Piepmeier EH, Bowman PD: cDNA microarray reveals altered cytoskeletal gene expression in space-flown leukemic $\mathrm{T}$ lymphocytes (Jurkat). FASEB J. 2001, 15: 1783-1785. 0892-6638

This PDF file was created after publication. 